\title{
On the Question of Energy and Power Potentials of the Electrode Materials in the Rechargeable Cells
}

\author{
Branimir N. Grgur \\ Faculty of Technology and Metallurgy, University of Belgrade, Karnegijeva 4, 11020 Belgrade, Serbia \\ E-mail: BNGrgur@tmf.bg.ac.rs
}

doi: $10.20964 / 2021.05 .46$

Received: 2 February 2021 / Accepted: 15 March 2021 / Published: 31 March 2021

\begin{abstract}
The paper considers galvanostatic discharge of different rechargeable cells. In the first part of the paper, the useful mathematical equations for the calculation of voltage, capacity, capacitance, energy, and power is given. In the second part of the paper, the proposal for the determinations of energy and power potentials of the electrode materials introducing the reference electrode as a reference point is discussed for different charge storage cells. The proposed analysis is applied on the polyaniline and lead-lead sulfate electrode discharge, and procedure how from the single electrode measurements, capacity, energy, and power of the hypothetical lead sulfate - polyaniline cell could be estimated.
\end{abstract}

Keywords: Battery; Supercapacitors; Supercapattery; Galvanostatic Discharge.

\section{$\underline{\text { FULL TEXT }}$}

(C) 2021 The Authors. Published by ESG (www.electrochemsci.org). This article is an open access article distributed under the terms and conditions of the Creative Commons Attribution license (http://creativecommons.org/licenses/by/4.0/). 